ARTÍCULO

\title{
CARNAVAL Y SECULARIZACIÓN \\ DISPUTAS EN TORNO A LOS BAILES DE MÁSCARAS EN LA CIUDAD DE MÉXICO EN 1831 Y 1840
}

CARNIVAL AND SECULARIZATION

DISPUTES ABOUT MASQUERADES IN MEXICO CITY

IN 1831 AND 1840

\author{
Cristóbal Alfonso SÁNCHEz UlLOA ${ }^{1}$ \\ Universidad Nacional Autónoma de México \\ Centro Peninsular en Humanidades y Ciencias Sociales \\ Becario posdoctoral \\ cristobalsanchezu@gmail.com
}

\section{Resumen}

Por medio de las discusiones en el ámbito público que los bailes de máscaras de 1831 y 1840 originaron en la ciudad de México, este artículo se acerca a las transformaciones de la sociedad postindependentista. Se aborda el proceso de secularización, en particular las expresiones anticlericales y la paulatina irrupción de actividades profanas en un tiempo otrora de recogimiento, como era la Cuaresma. Se analiza la pugna entre la Iglesia y el Estado por influir en la sociedad, así como el interés de los gobernantes por legitimarse y tener presencia entre los pobladores. Finalmente, se aborda la transformación de las mascaradas en un espectáculo público, encerrado entre las paredes de un teatro, fácil de vigilar y redituable para empresarios y autoridades, así como las opiniones que algunos letrados tuvieron sobre este proceso.

Palabras clave: secularización; anticlericalismo; bailes de máscaras; Ilustración; espacio público; espectáculo; diversiones públicas; modernidad.

\section{Abstract}

The present article approaches social changes in post-independent Mexico by examining public discussions about masquerades in Mexico City in 1831 and 1840. The secularization process, particularly anticlerical expressions and a gradual irruption of "profane" activities in retreat intervals as Lent, is explored. The dispute between Church and State to influence society, as well as rulers' concern for gaining legitimacy and presence among people, are also examined. Lastly, the transformation of masquerades into public performances within

${ }^{1}$ Este artículo es parte de la investigación que realicé como estudiante del doctorado en Historia en el Centro de Investigaciones y Estudios Superiores en Antropología Social (CIESAs) Peninsular, con el apoyo del Consejo Nacional de Ciencia y Tecnología (cOnACYT). Agradezco las sugerencias de mi directora de tesis, Julia Preciado, y de quienes leyeron alguna versión del texto. Y agradezco al Programa de Becas Posdoctorales de la Universidad Nacional Autónoma de México (UNAM), por el apoyo otorgado durante la redacción final del texto. 
easy-to-watch and private-public profitable theater halls, as well as some learned opinions about that process, are also approached.

Keywords: secularization; anticlericalism; masquerades; Enlightenment; public space; performance; public entertainment; modernity.

Información del artículo

Recibido: 30 de septiembre de 2019.

Aceptado: 19 de febrero de 2020.

DOI: $10.22201 /$ iih.24485004e.2020.59.70970

En fin, bola, bola, sobrinito mío, tú sabes que los bailes de máscara regularmente se vuelven boruca: con mil razones los escomulgaron los señores escomulgadores, y te escomulgaron a ti y a mí, y hoy nos quieren volver á escomulgar de nuevo... ${ }^{2}$

\section{Introducción}

A lo largo de la primera mitad del siglo xıx los bailes de máscaras adquirieron popularidad entre los habitantes de la ciudad de México; tanta, que para la década de 1840 ya se realizaban en los teatros de la urbe y durante la Cuaresma, tiempo en el que antes se proscribían. Este auge fue parte de las transformaciones en la sociedad y motivó álgidas discusiones.

En el presente artículo estudio dichas disputas en dos momentos específicos del proceso de florecimiento de las mascaradas: la Cuaresma de 1831, cuando las autoridades eclesiásticas intentaron prohibirlas, y los primeros bailes de máscaras públicos, efectuados en 1840 en el Teatro Principal de la ciudad. No estudio los bailes, lo que aconteció en ellos, ni los disfraces y sus implicaciones - salvo alguna excepción-. Me enfoco, más bien, en los debates que estas diversiones generaron en la esfera pública. Con ello doy cuenta de las tensiones que se encontraban presentes en la sociedad de la urbe en los primeros años de vida independiente: las que había entre Estado, Iglesia, sociedad y los representantes de las diferentes posturas políticas.

Los bailes de máscaras decimonónicos en la ciudad de México se inspiraron en los europeos de los siglos XVIII y xix. Éstos, a su vez, tomaron

${ }^{2}$ El Duende, t. I, 14 de marzo de 1840, 153. 
elementos del carnaval medieval y los adaptaron a la moral ilustrada. Mijail Bajtin explica esta transformación. Para el teórico literario ruso, durante la Edad Media y gran parte del Renacimiento "los espectadores no asisten al carnaval, sino que lo viven, ya que el carnaval está hecho para todo el pueblo. Durante el carnaval no hay otra vida que la del carnaval. Es imposible escapar, porque el carnaval no tiene ninguna frontera espacial". ${ }^{3}$ Esta inmersión de lo carnavalesco en todas las esferas sociales se modificó, según Bajtin, a partir de la segunda mitad del siglo XVII:

Por una parte se produce una estatización de la vida festiva, que pasa a ser una vida de gala; y por la otra se introduce a la fiesta en lo cotidiano, es decir que queda relegada a la vida privada, doméstica y familiar. [...] La fiesta casi deja de ser la segunda vida del pueblo, su renacimiento y renovación temporal. ${ }^{4}$

En su libro sobre las diversiones públicas en la ciudad de México durante el Siglo de las Luces, Juan Pedro Viqueira le dedica atención a esta festividad. El historiador ve en la capital de Nueva España una transformación similar a la que observa Bajtin. El regocijo popular, callejero, en el que se invertía - y al mismo tiempo se reforzaba- el orden social, fue combatido y desterrado del centro de la ciudad por las autoridades civiles y eclesiásticas. Para Viqueira, este combate simbolizó la "alteración del equilibrio entre los diversos grupos sociales en provecho de los poderosos y del Estado". Y fue el "resultado del avance de una modernidad uniformadora que empezaba a borrar todo resabio de las tradicionales ambigüedades sociales". ${ }^{5}$

Tras ser marginado, el carnaval resurgió con una nueva forma en el segundo cuarto del siglo xIx. Las élites y los sectores medios de la ciudad de México lo condensaron en los bailes de máscaras. Lo convirtieron en un carnaval contenido, con límites espaciales y temporales definidos, despojado de gran parte de su esencia - hasta aburrido, podría decirse-. Viqueira lo caracteriza como "una pálida copia, una desnaturalización burguesa que preludiaba su total desaparición”. 6

${ }^{3}$ Mijail Bajtin, La cultura popular en la Edad Media y en el Renacimiento. El contexto de François Rabelais, trad. de Julio Forcat y César Conroy (Madrid: Alianza Universidad, 1998), 13.

${ }^{4}$ Bajtin, La cultura popular en la Edad Media..., 36-37.

${ }^{5}$ Juan Pedro Viqueira, ¿Relajados o reprimidos? Diversiones públicas y vida social en la ciudad de México durante el Siglo de las Luces (México: Fondo de Cultura Económica, 1987), 139-149.

${ }^{6}$ Viqueira, ¿Relajados o reprimidos?..., 148. 
Mas esta "pálida copia" o intento de resucitar una fiesta otrora exultante dice mucho sobre la sociedad postindependentista. No aburre conocer las discusiones que generó, los procesos sociales que evidenció y las transformaciones en el tiempo secular y ritual. Estos son los temas que abordo en las siguientes páginas.

En los primeros apartados estudio la respuesta que generó el intento de las autoridades católicas de la ciudad de prohibir las mascaradas en 1831. En las disputas se manifiesta la secularización que comenzó desde el siglo XVIII y que no detuvo el cambio en la realidad política. Particularmente, se aprecian el abierto cuestionamiento o desafío a las autoridades y figuras eclesiásticas y a sus disposiciones, la pérdida de influencia del clero en la sociedad y las acciones del Estado destinadas a ocupar espacios en los que la Iglesia y la religión predominaban.

Posteriormente abordo los bailes de máscaras de 1840 en el Teatro Principal. Estas diversiones evidencian que los espacios públicos de recreación se delimitaron cada vez más; de la calle pasaron a sitios cerrados, a horarios definidos. Este cambio guardó una relación estrecha con la intención del Estado mexicano de vigilar a los pobladores. Junto con lo anterior, exploro las diferentes opiniones que algunos letrados tenían sobre los bailes de máscaras. Finalmente, esbozo el crecimiento de los bailes públicos hacia mediados de siglo, cuando se convirtieron en un buen negocio, del cual empresarios y autoridades buscaron obtener ganancias.

\section{La excomunión}

El domingo 6 de marzo de 1831, los católicos de la ciudad que se alistaban a portar máscaras y disfraces se enteraron de que, si lo hacían, quedarían excomulgados. Lo supieron por un edicto que publicó ese día el cabildo eclesiástico. ${ }^{7}$ En el documento los canónigos se dijeron dolidos por el aumento de la "impiedad" y la "relajación de costumbres"; en particular, porque sus diocesanos convertían los domingos y el tiempo de Cuaresma en "días de diversiones, de mayores escándalos, de mayor lujo y de mayor prostitución”. Por ello, declararon "prohibidas para siempre las concurrencias

7 "Domingo 6 de marzo de 1831", Carlos María de Bustamante, Diario histórico de México 1822-1848, ed. de Josefina Zoraida Vázquez Vera y Héctor Cuauhtémoc Hernández Silva (México: El Colegio de México/Centro de Investigación y Estudios Superiores en Antropología Social, 2001), CD-ROM. 
á las máscaras y sus bailes [...] bajo la pena de EXCOMUNión MAYOR ipso facto incurrenda". Y aquellos que los organizaran, serían excomulgados de por vida: "A quienes no será lícito tratar, a quienes privaremos la entrada en nuestros templos, serán sepultados en lugares profanos, agravando los anatemas, $[\ldots]$ en condigno castigo de su obstinación y rebeldía". ${ }^{\circ}$

La medida no cayó bien entre los entusiastas de las mascaradas. A pesar de que la institución católica y las leyes prohibían ese tipo de recreos en carnestolendas y durante la Cuaresma, las autoridades civiles, incluso las mismas religiosas, solían tolerarlas. ${ }^{9}$ Y los bailes eran populares entre muchos feligreses. Así se aprecia en las reacciones que el documento provocó. Los editores del periódico El Sol, por ejemplo, advirtieron: "Siempre que el poder eclesiástico no se limite a sus deberes y se le permita salir una línea más de su órbita, la libertad la consideramos muy amenazada y estaremos expuestos a caer bajo el despotismo más feroz" ${ }^{10}$ Se mostraron sorprendidos por las facultades que el cabildo eclesiástico se adjudicó. Esta corporación, formada por clérigos de la catedral metropolitana, ocupaba en ese momento el lugar del arzobispo, por lo que era la mayor autoridad católica en la ciudad (la Santa Sede no había reconocido la independencia del país, y el portador de la mitra de México, Pedro Fonte, se retiró a España desde 1821). ${ }^{11}$ Por ello, el edicto tenía tanta importancia.

Carlos María de Bustamante calificó la decisión del cabildo eclesiástico como una "gran fechoría". En su diario personal anotó que era obra "del muy viejo, muy pesado y muy tonto canónigo” Joaquín Ladrón de Guevara, quien presidía el cabildo eclesiástico. ${ }^{12}$ Bustamante publicó un suplemento en la Voz de la Patria en el que se pronunció contra el edicto, porque se publicó sin la venia del gobierno. Esto es, por no haber considerado a la autoridad civil en una decisión que afectaba gravemente a la población. Además, la pena de excomunión le parecía desproporcionada y contraria a la "lenidad y dulzura" que debía tener la Iglesia. Bustamante creía que

${ }^{8}$ Archivo General de la Nación (en adelante AGN), Justicia Archivo, v. 121, exp. 1 [2], f. 2.

${ }_{9}^{9}$ Verónica Zárate Toscano, "Del regocijo a la penitencia o del carnaval a la cuaresma en la ciudad de México en el siglo xIx”, en Gozos y sufrimientos en la historia de México, coord. de Pilar Gonzalbo y Verónica Zárate (México: El Colegio de México/Instituto de Investigaciones Dr. José María Luis Mora, 2007), 207-208.

${ }^{10}$ El Sol, 6 de marzo de 1831, citado en Luis Reyes de la Maza, El teatro en México durante la independencia (1810-1839) (México: Universidad Nacional Autónoma de México, Instituto de Investigaciones Estéticas, 1969), 262.

${ }^{11}$ Agradezco a Brian Connaughton esta aclaración.

12 “Domingo 6 de marzo de 1831", Bustamante, Diario histórico de México... 
muchos católicos compartían su sentir sobre las diversiones en el tiempo de Cuaresma. Las justificaba afirmando que los individuos necesitaban momentos y espacios de desahogo. Dado que no había teatros, los bailes eran preferibles a que los hombres pasaran la noche "en un garito infame de prostitución, o jugando la fortuna de sus hijos y la dote de su esposa". ${ }^{13}$ Los bailes alejaban a los hombres de diversiones que la Iglesia y otras personas con ideas similares a las del escritor consideraban peores. Eran un mal menor cuando se comparaban con otros entretenimientos; por ello los gobernantes no restringían éstas ni otras diversiones en el tiempo de Cuaresma. Quizá lo que aumentaba la preocupación de los clérigos era que ciertos bailes se realizaran en casas, lejos de la mirada pública. Lo que imaginaban —o sabían- que acontecía en los bailes de máscaras para ellos era reprobable. ${ }^{14}$

Otras expresiones contrarias a la decisión del cabildo eclesiástico fueron más drásticas. El domingo 6 de marzo, al conocer el contenido del edicto, el coronel Félix Merino se presentó en el portal de Mercaderes exigiendo que lo dieran por excomulgado, pues fue él quien promovió los bailes. Esa noche se disfrazó "de granadero gastador, con largas y espesas barbas", con un fusil al hombro, y siguió criticando públicamente a los canónigos. ${ }^{15}$ Pero el asunto no se quedó ahí. Merino mandó un oficio desafiante a los autores del edicto. Para ahorrarles la pesquisa, les informó que él era uno de los autores de los bailes. Y añadió:

Cristianos $\mathrm{p}[\mathrm{o}] \mathrm{r}$ principio pero no fanáticos la mayor parte de los $\mathrm{q}[\mathrm{u}] \mathrm{e}$ concurrimos á las privadas diversiones de máscaras; no tememos en manera alguna los efectos de esa arma temible de la Yglesia con q[u]e se aterra á los déviles; y cuyos filos se han embolado a fuerza de usarla tan imprudentem[en]te como lo a hecho V[uestra] S[eñoría] Y[lustrísima] ahora.

V.S.Y. me amenaza con privarme de la concurrencia a los templos y de la sepultura Ec[lesiásti]ca. En q[uan]to a lo prim[er]o como el Ser Supremo pueda adorarse en todas partes me curo poco de semejante prohivision; y en q[uan]to a

13 "Observaciones legales sobre el edicto publicado el día 6 del presente mes por el Cabildo Eclesiástico de México, contra las máscaras y bailes”, Voz de la Patria, 10 de marzo de 1831.

${ }^{14}$ Según mencionó un escritor anónimo en El Sol, se llegó a decir que el edicto se publicó "porque hubo bailes de máscaras de hombres y mujeres desnudos y solo las caras cubiertas”. El Sol, 2 de abril de 1831, citado en Reyes de la Maza, El teatro en México..., 263-264.

15 “Domingo 6 de marzo de 1831”, Bustamante, Diario histórico de México... 
lo Segundo me es muy indiferente ser enterrado en qualquier lugar, mucho mas q[ue] no siéndolo en sagrado ahorraré por lo menos los D[e]r[ech]os. Si por la excomunión se entiende la incomunicación que debe haver entre V.S.Y. y yo, puedo asegurarle q[ue] hase mucho tiempo estoy excomulgado y q[ue] pienso [estarlo] toda mi vida. ${ }^{16}$

Merino escribió su oficio el domingo mismo en que se publicó el edicto. Tres días después le envió al cabildo eclesiástico una nueva versión en la que mantuvo su postura, pero añadió ideas con un tono más sereno. Mencionó que no creía estar excomulgado y que consideraba nulo el castigo por ser injusto. Preguntaba por la caridad y la piedad que predicaba la Iglesia y sugería a los canónigos revocar su decisión "para reconciliarse con el público, cuya tranquilidad ha expuesto sobremanera, dando pábulo á los enemigos del orden, para promover trastornos de otro género". ${ }^{17}$

Los trastornos, según apuntaron otros, los causó el mismo Merino con sus acciones. Carlos María de Bustamante anotó que la noche del domingo 6 de marzo de 1831 se formaron "muchos corrillos de gente de igual calaña" que imitaron la actitud del militar. ${ }^{18}$ El cabildo catedralicio, por su parte, cuando envió una copia del oficio al Ministerio de Justicia y Negocios Eclesiásticos, mencionó que "la publicidad que el mismo Merino dio a su exposición" produjo "entre los sensatos, y aun libertinos un general escándalo". ${ }^{19}$ Fue una noche agitada en la ciudad, como puede entenderse.

Los "enemigos del orden" a los que aludió el coronel Merino en su escrito podrían haber sido opositores del vicepresidente Anastasio Bustamante, quien se encontraba al frente del gobierno desde inicios de 1830. Si bien el general contó con el beneplácito de varios sectores cuando asumió el poder, para ese momento ya se había enemistado con varios.

Bustamante llegó al poder tras un levantamiento que él mismo encabezó, en diciembre de 1829, en contra del presidente Vicente Guerrero. El pronunciamiento lo apoyaron diferentes sectores, que tenían en común el descontento con la administración de Guerrero: a los "hombres de bien” ${ }^{20}$

${ }^{16}$ AGN, Justicia Archivo, v. 121, exp. 1 [2], fs. 15-16.

17 AGN, Justicia Archivo, v. 121, exp. 1 [2], fs. 15-16.

18 “Domingo 6 de marzo de 1831", Bustamante, Diario histórico de México...

${ }^{19}$ AGN, Justicia Archivo, v. 121, exp. 1 [2], f. 14.

${ }^{20}$ Como explica Michael P. Costeloe, La República Central en México, 1835-1846. "Hombres de bien" en la época de Santa Anna (México: Fondo de Cultura Económica, 2000), 35, el "hombre de bien" provenía de los sectores medios. No se reconocía tanto por su postura política, más bien, por los valores que defendía. "Era un creyente católico, dotado de un 
y a los exescoceses que se oponían al carácter popular del régimen, se unieron algunos yorkinos que fueron relegados por la administración, así como un gran número de oficiales del ejército. Y el descontento creció a partir de que el Congreso le concedió facultades extraordinarias a Guerrero, por motivo de la expedición española de reconquista. Los políticos de los estados vieron amenazada su soberanía por las medidas fiscales, los periodistas sufrieron la censura y las autoridades eclesiásticas, junto con los comerciantes y propietarios de fincas del Distrito Federal, fueron forzados a otorgar un préstamo al gobierno. Todo ello dejó a Guerrero con muy poco apoyo en el momento del levantamiento, orillándolo a dejar el puesto. ${ }^{21}$

Así, Anastasio Bustamante se colocó al frente del país, sostenido por una coalición heterogénea y, por lo mismo, frágil. Aunado a ello, su gobierno enfrentó un problema de legitimidad desde un inicio, ya que había prometido restaurar el orden constitucional; sin embargo, llegó al poder por medio de una rebelión, y no favoreció el regreso de Manuel Gómez Pedraza, quien era el presidente constitucional y se encontraba en el exilio. Asimismo, se sirvió de los militares para controlar a los opositores y darle mayor fuerza al poder ejecutivo, ${ }^{22}$ lo cual hizo surgir pronto el descontento.

A lo largo de 1830, además de esta endeble legitimidad, el gobierno enfrentó el levantamiento armado de Vicente Guerrero y Juan Álvarez en el sur del país, que se prolongó hasta 1831. A inicios de dicho año, Guerrero fue capturado. Un tribunal militar lo juzgó y sentenció a muerte. El exinsurgente fue fusilado el 14 de febrero de 1831.

Tras estos hechos, la coalición que llevó al poder a Bustamante siguió fracturándose. Además del descontento y las críticas, la ejecución de Guerrero provocó que los moderados que en un inicio lo habían apoyado se

fuerte sentimiento del honor y la moral, y de suficientes medios financieros para mantener cierto estilo de vida."

${ }^{21}$ Alfredo Ávila, “La presidencia de Vicente Guerrero”, en Gobernantes mexicanos, v. 1, 1821-1910, coord. de Will Fowler (México: Fondo de Cultura Económica, 2008), 91-95.

${ }^{22}$ Esto no significó que el régimen instaurara un centralismo de facto, algo de lo que lo acusaron sus opositores contemporáneos. Como señala Catherine Andrews, Entre la espada y la Constitución. El general Anastasio Bustamante 1780-1853 (Ciudad Victoria: Universidad Autónoma de Tamaulipas/H. Congreso del Estado de Tamaulipas, LX Legislatura, 2008), 140-152, Bustamante se pronunció por restablecer el orden constitucional -federalista-; y si bien destituyó a funcionarios en los estados, estas medidas se destinaron a quitar del poder a los yorkinos, no a cambiar el sistema de gobierno. 
volvieran en su contra. ${ }^{23}$ En la capital, al conocerse la noticia no hubo mayores sobresaltos, en gran medida porque muchos de los enemigos del gobierno habían sido exiliados; ${ }^{24}$ sin embargo, sí hubo muestras de desaprobación, sobre todo en la prensa. Algunos impresos de oposición salieron a la luz, y también varios editores de $E l$ Sol, periódico que apoyaba al régimen, renunciaron a la publicación. ${ }^{25}$

Fue en ese contexto en el que ocurrió la discusión sobre las mascaradas y la excomunión. Aunque en esas semanas no surgieron altercados, una movilización de corte popular no era imposible en la mente de quienes detentaban el poder. El motín del Parián, de finales de 1828, seguía fresco en las mentes de los "hombres de bien", y el temor a la disolución social perduraba. Quizá por todo lo anterior, Félix Merino buscó matizar —aunque levemente- su reclamo para no atizar las llamas en un momento en que se mantenía una frágil estabilidad.

Las diversiones podían servir como una válvula de escape para las tensiones políticas. Carlos María de Bustamante lo expresó así en su artículo de la Voz de la Patria, en el que también afirmó: "Además de que proporcionan un desahogo al ánimo, sirven para que los hombres se amisten y reconcilien, principalmente en una época en que han estado divididos por partidos, se ilustren y perciban aquel deleite de una sociedad honesta y encantadora”. ${ }^{26}$ Los integrantes del gobierno pensaban igual; las veían como un respiro. Esto lo demuestra el hecho de que, en cuanto se publicó el edicto, el ministro de Justicia y Negocios Eclesiásticos, José Ignacio Espinosa, se comunicó con el cabildo eclesiástico a nombre del vicepresidente Bustamante. Le informó, entre otras cosas, que en adelante no debería promulgar ningún decreto sin que antes lo conociera el gobierno. Y le pidió que explicara a los feligreses que la prohibición de las máscaras "para siempre” se refería sólo al tiempo de Cuaresma. ${ }^{27}$

Los militares que sostenían al régimen sabían que no convenía alterar los ánimos de la población. Un mandato como el que publicó el cabildo eclesiástico podía generar descontento e incluso desmanes. Y la experiencia

${ }^{23}$ Will Fowler, Santa Anna. ¿Héroe o Villano? (México: Crítica, 2018), 222-224.

${ }^{24}$ Andrews, Entre la espada y la Constitución..., 192.

${ }^{25}$ Laura Martínez Domínguez, "El Sol, 1823-1835. Un periódico político durante la Primera República Federal” (tesis doctoral, Universidad Nacional Autónoma de México, 2018), 241-246.

26 “Observaciones legales”, Voz de la Patria, 10 de marzo de 1831.

${ }^{27}$ AGN, Justicia Archivo, v. 121, exp. 1 [2], fs. 6-7. 
reciente dictaba que cualquier sobresalto público podía ser aprovechado por opositores para desencadenar un pronunciamiento o una rebelión.

Distinto a lo que muchos temían, los ánimos no se alteraron gravemente, más allá de la agitación provocada por Merino la noche del 6 de marzo. En gran medida porque Merino fue uno de los tantos que desafiaron el edicto. El gobernador del Distrito Federal ya había dado licencia a los organizadores de bailes. Y éstos se efectuaron aun a sabiendas de la pena anunciada. ${ }^{28}$ Así, la amenaza de la excomunión no persuadió a los habitantes de la ciudad y sí, en cambio, desprestigió a los canónigos y su decisión, pues fueron atacados desde distintos frentes. Probablemente para ellos fue difícil aceptar someterse a la voluntad del gobierno civil. Después de diez días respondieron al ministro Espinosa y al vicepresidente Bustamante en un tono sumiso. Refirieron y agradecieron la protección que el gobierno les daba; se comprometieron a consultar con el gobierno los decretos sobre prohibiciones o censuras que pudieran alterar el orden público; ofrecieron enviarle al gobernador del distrito copias de dichos documentos; y prometieron publicar un nuevo edicto - que tardó un año-que restringiera la censura sólo a la Cuaresma y a procesiones públicas. ${ }^{29}$

En un inicio las autoridades eclesiásticas vieron con mejores ojos al gobierno de Anastasio Bustamante que al de Vicente Guerrero. El alto clero era parte de los "hombres de bien", quienes temían la participación política de sectores populares, promovida por algunos políticos o militares yorkinos. Además, Guerrero, como se vio líneas atrás, haciendo uso de sus facultades extraordinarias exigió un préstamo forzoso al cabildo catedralicio de México. Por ello apoyaron al gobierno de Bustamante, quien los tranquilizó en lo referente a sus bienes y les garantizó que mantendrían su autonomía y su injerencia en ámbitos como la educación..$^{30}$ No obstante, el caso que aquí trato muestra que, aun con un gobierno afín, para la Iglesia en México era imposible recuperar las facultades de que gozó en los siglos previos y que comenzó a perder desde finales del siglo XVIII. El régimen bustamantista no le permitió a la autoridad eclesiástica una prohibición que podía afectar la estabilidad. El cabildo tuvo que cumplir la voluntad de la autoridad para seguir disfrutando de su protección.

${ }^{28}$ AGN, Justicia Archivo, v. 121, exp. 1 [2], fs. 3-4; "Domingo 6 de marzo de 1831”, Bustamante, Diario histórico de México...

${ }^{29}$ AGN, Justicia Archivo, v. 121, exp. 1 [2], fs. 9-12.

${ }^{30}$ Andrews, Entre la espada y la Constitución..., 162. 
El Estado mexicano, en proceso de formación durante esos años, precisaba contrarrestar y subordinar a cualquier institución que ostentara más poder. Los gobiernos republicanos, centralistas o federalistas, buscaron introducirse en la mayor cantidad de ámbitos y legitimarse. La Iglesia era un obstáculo para conseguir ese objetivo. ${ }^{31}$

\section{Los "irreligiosos disfraces"}

En la respuesta de los clérigos al gobierno están los motivos principales - $\mathrm{O}$ verdaderos- por los cuales promulgaron el edicto con un castigo tan severo: pidieron al gobierno que tomara providencias para que las máscaras no pasaran de una "diversión honesta" y que prohibiera usar disfraces de santos y de "personas eclesiásticas y religiosas". La burla a su jerarquía mediante esta práctica, que los sacerdotes consideraban impía, era lo que más les inquietaba. El vicepresidente coincidió en esto y se comprometió a cooperar; pero, al igual que a los gobernantes de otros años, le fue imposible evitar que los asistentes a los bailes se vistieran de personajes religiosos. ${ }^{32}$ Tal parece que estos disfraces eran comunes antes de 1831 y lo siguieron siendo años después.

Implícito en la postura del cabildo estaba también el temor por el roce de los cuerpos en los bailes. No era una preocupación nueva, pero era importante para los religiosos, sobre todo por ser los días previos a la Cuaresma. El cuerpo, aleccionaba el clero, era el contenedor del alma y debía prepararse para recibir a la divinidad por medio de la eucaristía. A ojos de los clérigos, el baile favorecía el descontrol de los impulsos y de los sentidos, lo que abría la puerta al demonio. ${ }^{33}$ Las autoridades eclesiásticas luchaban por mantener el control sobre los cuerpos de los fieles, el cual paulatinamente también perdían.

La otra gran preocupación del cabildo, que sí explicitó en su respuesta, era que circularan libros que originaban la "relajación de costumbres";

${ }^{31}$ Enrique Dussel, "La Iglesia en el proceso de la organización nacional y de los Estados en América Latina (1830-1880)", en Estado, Iglesia y sociedad en México. Siglo XIX, coord. de Álvaro Matute, Evelia Trejo y Brian Connaughton (México: Universidad Nacional Autónoma de México, Facultad de Filosofía y Letras/Miguel Ángel Porrúa, 1995), 63.

${ }^{32}$ AGN, Justicia Archivo, v. 121, exp. 1 [2], fs. 9-12.

${ }^{33}$ Alain Corbin, "El dominio de la religión", en Historia del cuerpo, v. 2, De la Revolución Francesa a la Gran Guerra, coord. de Alain Corbin (Madrid: Taurus, 2005), 57-86. 
relajación de la cual eran prueba los "irreligiosos disfraces". Desafortunadamente, no mencionó el cabildo las obras que deseaba censurar o prohibir. Quizá en el escrito del coronel Félix Merino se pueden conocer las ideas que dichos textos difundían.

La parte más interesante del fuerte reclamo del militar es la que expresa su idea de la jerarquía eclesiástica: Merino se dijo inmune a la amenaza de excomunión. Dado que la Iglesia la había usado como instrumento para regir o restringir los actos de los católicos, ya no pesaba lo mismo que en décadas anteriores. Merino desafió así a la jerarquía eclesiástica. Orgulloso, aceptó que llevaba un buen tiempo lejos de ella y planeaba seguir así. Planteó que Dios podía adorarse sin entrar a los templos, y no veía en riesgo su salvación por no ser enterrado en un lugar sagrado. Merino ejemplificó, así, una de las transformaciones ideológicas de la época. A raíz de la Ilustración, muchos individuos que tenían acceso a la educación creían en la divinidad, pero en una divinidad que no exigía mayor adoración que la gratitud. La actitud de dichos individuos hacia la religión y hacia el clero en particular era hostil. ${ }^{34}$ Merino parece haber adoptado esta postura que muestra el cuestionamiento de las visiones ontológicas dominantes, uno de los rasgos fundamentales de la modernidad. ${ }^{35}$

El coronel esgrimió críticas a la Iglesia que fueron y han sido comunes. Al referir los derechos que cobraba por los entierros, aludió a su enriquecimiento a expensas de los fieles. Y, de forma más clara, expresó que cuando la religión de Jesucristo tomó un "carácter duro y perseguidor" causó "infinitos males á la Iglesia" y llenó "el Mundo de sangre". ${ }^{36}$

Las expresiones de Merino reflejan la influencia de la Ilustración. Desde el siglo XVIII y a lo largo del XIX la Iglesia sufrió por el proceso de seculari-

${ }^{34}$ Eric Hobsbawm, La era de la revolución 1789-1848 (Barcelona: Crítica, 2011), 223.

${ }^{35}$ Me baso en la propuesta de Shmuel N. Eisenstadt, "Some Observations on Multiple Modernities", en Reflections on Multiple Modernities: European, Chinese and Other Interpretations, ed. de Dominic Sachsenmaier y Jens Riedel con Shmuel N. Eisenstadt (Leiden: Brill, 2002), 27-41, quien caracteriza el programa cultural y político de la modernidad con los siguientes rasgos: la existencia de más de una visión ontológica y la capacidad de poner estas mismas en duda; el énfasis en la autonomía del hombre, en su capacidad reflexiva, en la posibilidad que tiene de desempeñar diferentes papeles en la sociedad, de pertenecer a diferentes comunidades y de influir conscientemente en la sociedad y en la naturaleza; la legitimidad de diferentes intereses sociales e individuales y de diversas interpretaciones del bien común; la transformación del orden político (este campo se abre a diferentes actores y se modifica por la interacción entre centro y periferia); el surgimiento de nuevas identidades colectivas; y la autopercepción de las sociedades como "modernas".

${ }^{36}$ AGN, Justicia Archivo, v. 121, exp. 1 [2], fs. 15-16. 
zación, que era parte de la ideología ilustrada y, en general, de la modernidad. La religión paulatinamente dejó de ser el centro alrededor del cual giraban las ideas y los actos de los individuos o las sociedades. El Estado borbón y después el mexicano contribuyeron a esta transformación en su afán por imponerse sobre la Iglesia católica. Le quitaron facultades, restaron su influencia en la sociedad y fijaron la mirada en sus propiedades.

Una manifestación importante de la secularización fue el anticlericalismo, el cual creció después de la Independencia. En la década de 1820 liberales como José Joaquín Fernández de Lizardi repudiaron la riqueza del alto clero, subrayaron la inutilidad de los frailes y criticaron la negativa de la Iglesia a mostrar fidelidad al nuevo régimen. ${ }^{37}$ Las discusiones en torno a la institución católica fueron frecuentes. Temas como el patronato, la tolerancia religiosa, las propiedades clericales y su participación en la educación motivaron conflictos desde la Independencia. ${ }^{38}$

Los ataques al clero fueron más intensos en coyunturas específicas. A inicios de 1827, por ejemplo, se supo de una conspiración encabezada por el fraile dieguino Joaquín Arenas para reinstaurar la monarquía española en México. Además de aumentar la hispanofobia del momento, el caso desató fuertes expresiones contra los clérigos. Tras la ejecución de Arenas, en junio de 1827, un escritor anónimo atacó a frailes y curas. Para "ilustrar al pueblo", pidió acabar con algunos de estos personajes: "Una poca de sangre bendita derramada a tiempo salvará la que debería correr de millones". ${ }^{9}$

En 1831, cuando el cabildo eclesiástico publicó su edicto, el ambiente no era tan abiertamente contrario al clero. Ello no impidió manifestaciones como las de Félix Merino, lo cual muestra que individuos de diferentes ideologías, de distintas facciones políticas o de variadas sensibilidades religiosas fueron receptivos al anticlericalismo. Puede entenderse entonces la preocupación que el cabildo eclesiástico manifestó en torno a los bailes de máscaras. Probablemente entre las publicaciones que deseaban censurar,

${ }^{37}$ José Enrique Covarrubias, "Inútil e insociable. La Iglesia católica según la crítica sociológica de Fernández de Lizardi, Prieto y Ramírez, 1821-1876”, en El anticlericalismo en México, coord. de Franco Savarino y Andrea Mutolo (México: Cámara de Diputados/Instituto Tecnológico y de Estudios Superiores de Monterrey/Miguel Ángel Porrúa, 2008), 287-288.

${ }^{38}$ Marta Eugenia García Ugarte, “Anticlericalismo en México 1824-1891”, en El anticlericalismo en México, coord. de Franco Savarino y Andrea Mutolo (México: Cámara de Diputados/Instituto Tecnológico y de Estudios Superiores de Monterrey/Miguel Ángel Porrúa, 2008), 320.

${ }^{39}$ Citado en Torcuato S. di Tella, Política nacional y popular en México, 1820-1847 (México: Fondo de Cultura Económica, 1994), 195-197. 
pero que no mencionaron por nombre, se encontraban aquellas que contenían las ideas anticlericales. También las que promovían la tolerancia religiosa, que conllevaba la disminución de la influencia del clero católico en la sociedad y que defendían personajes como Fernández de Lizardi y Lorenzo de Zavala. En esa misma Cuaresma de 1831, se difundió el Ensayo sobre tolerancia religiosa, de Vicente Rocafuerte, lo cual ilustra el ambiente que impregnó las diversiones y las discusiones que las aludieron. ${ }^{40}$

En la respuesta del cabildo eclesiástico al gobierno no aparece la firma del canónigo Joaquín Ladrón de Guevara, a quien Carlos Bustamante adjudicó la autoría del edicto y a quien tildó de "muy viejo, muy pesado y muy tonto”. Tal vez para dicho sacerdote resultaba difícil ceder. Él representaba un resabio del tiempo anterior a la Independencia. El edicto bien podría verse como un último intento del clero, en particular de personajes como Guevara, por influir en la sociedad y por decidir pasando por alto al Estado. Sin embargo, la "relajación" o el cambio de las costumbres y el menosprecio a las figuras de la Iglesia parecía inevitable. Ciertos gobernantes pensaban de forma similar, pero esto era una preocupación menor comparada con otras como la situación política y social, la crisis económica o la constante amenaza de un pronunciamiento.

Es sabido que la religión católica y la Iglesia desempeñaron un papel importante durante todo el siglo XIX. La Independencia no rompió de forma tajante ni mucho menos cambió en profundidad la religiosidad de la sociedad mexicana. Lo que se modificó considerablemente fue la relación del Estado con la autoridad eclesiástica. Muchos gobernantes intentaron disminuir la influencia del clero entre la población y disponer de los bienes eclesiásticos. La Iglesia rivalizaba con la autoridad civil en la búsqueda por obtener la fidelidad de los ciudadanos. ${ }^{41}$

El proceso de secularización, surgido desde antes de la Independencia, avanzaba con un ritmo irregular: a veces acelerado, a veces lento. Aun durante la administración de los gobiernos más cercanos a la Iglesia podía apreciarse dicho proceso, como es el caso que he referido.

Así, con todo y edicto, los pobladores de la ciudad asistieron a los bailes de máscaras. A principios de abril de 1831, El Sol publicó un remitido en el que su autor, "Argos", afirmó que, como en otros años, concurrió a

${ }^{40}$ El Sol, 6 de abril de 1831, 4; Charles A. Hale, El liberalismo mexicano en la época de Mora (1821-1853) (México: Siglo XXI, 2005), 168-169.

${ }^{41}$ Hale, El liberalismo mexicano..., 129. 
varias de estas diversiones. En ellas encontró a "un fraile, un beato con su beata, una muerte, etcétera". ${ }^{42}$ El edicto fracasó para los fines que planearon los sacerdotes.

A pesar de ello, el 3 de marzo de 1832 - un año después - el cabildo eclesiástico publicó un nuevo documento en el que afirmó que la prohibición produjo el efecto deseado, por lo que la levantaron, excepto en lo referente al uso de disfraces de santos y religiosos. Este nuevo documento lo publicaron hasta que el gobierno de Bustamante los presionó y les recordó a qué se habían comprometido varios meses atrás. ${ }^{43}$ Definitivamente, los miembros del cabildo se engañaron al afirmar que su edicto había funcionado. O mejor dicho, no quisieron mostrarse sometidos a la voluntad del gobierno y derrotados ante la opinión predominante el año anterior.

La postura de "Argos" resulta interesante. Para él los disfraces no eran un gran problema, pero sí lo eran las representaciones que ocurrían durante la Semana Santa en los barrios de la ciudad. Los "centuriones a caballo" y los "fariseos enmascarados con ridículas figuras" en las procesiones y en los templos le parecían profanos. Al igual que la venta de figuras de religiosos, santos, cruces y otras imágenes como juguetes para los niños. Para “Argos", lo que realmente ponía en ridículo al catolicismo era la religiosidad popular. El escritor añadió: "Si en tiempos menos ilustrados que los presentes, se consideraron las prácticas dichas de utilidad a los cristianos para enseñarlos, yo estoy persuadido de que ya no deben de usarse en los términos referidos”. Se preguntó: “¿Y qué dirán de ellas los extranjeros que nos observan?". ${ }^{44}$

Como muchos de sus contemporáneos, “Argos" se asumía en una época ilustrada. En su opinión los bailes de máscaras se acoplaban bien a ella. Recordemos que Carlos María de Bustamante también consideraba que en esas diversiones los hombres podían ilustrarse, y afirmó que en Europa y en la misma Roma "los primeros personajes" se divertían en las mascaradas. También el ministro de justicia, José Ignacio Espinosa, refirió que en Roma se llevaban a cabo esas diversiones. ${ }^{45}$ Por estas razones a los letrados les preocupaba tanto la opinión que los habitantes y viajeros extranjeros de la ciudad, sobre todo los europeos, se formaban de la sociedad mexicana. Eran

${ }^{42}$ El Sol, 2 de abril de 1831, citado en Reyes de la Maza, El teatro en México..., 263-264.

${ }^{43}$ AGN, Justicia Archivo, v. 121, exp. 1 [2], f. 25.

${ }^{44}$ El Sol, 2 de abril de 1831, citado en Reyes de la Maza, El teatro en México..., 263-264.

${ }^{45}$ AGN, Justicia Archivo, v. 121, exp. 1 [2], fs. 3-4; "Observaciones legales”, Voz de la Patria, 10 de marzo de 1831. 
ellos quienes definían qué tan ilustrados eran los mexicanos. Sin embargo, esa cualidad resultaba ambigua. Lo que para algunos era ilustrado, para otros era lo contrario. Ante lo resbaloso del adjetivo, había luchas por apropiárselo. Una de ellas se desarrolló nueve años después en otra discusión en torno a las mascaradas.

\section{Los bailes de máscaras públicos y la Ilustración}

Hacia 1840, el Teatro Principal y el Teatro de los Gallos eran los mayores escenarios de la ciudad, ${ }^{46}$ donde se presentaban las compañías de drama y ópera de los primeros años del periodo postindependentista ${ }^{47}$ Los espectáculos, sin embargo, no siempre eran rentables, y a los empresarios y directores les costaba trabajo mantener en buen estado los teatros, así como consolidar a las compañías. Los artistas, muchos de ellos extranjeros (españoles e italianos, principalmente), terminaban sus contratos y partían a buscar mejor suerte en otros sitios. Frente a estas dificultades, los hombres de espectáculo tenían que pensar en otras diversiones que les permitieran mejorar sus ingresos. Las mascaradas se convirtieron en una buena alternativa.

A finales de 1839 la compañía dramática del Teatro Principal, dirigida por el español Miguel Valleto, pidió permiso al gobernador del departamento de México para organizar bailes de máscaras públicos en ese recinto en marzo de 1840. Nunca antes se habían realizado diversiones similares ahí. Como se aprecia en el apartado anterior, era costumbre hacerlas en casas o en sitios privados.

En su solicitud la compañía aseguró que en "todas las Naciones", desde la Antigüedad, habían existido momentos en los que las distinciones sociales se borraban. Que en Francia, Inglaterra “y la Europa toda incluso la

${ }^{46}$ El Teatro Principal o Coliseo, construido en el siglo XviII, se encontraba en la calle de Coliseo (hoy Bolívar, entre 16 de septiembre y Madero); el espacio donde se encontraba, actualmente lo ocupa un edificio del Poder Judicial de la Federación. El Teatro de los Gallos, llamado también Provisional o de la Ópera fue construido en la década de 1820 en lo que era el palenque de Gallos. Se encontraba en la calle de las Moras, seis cuadras al norte de la Plaza Mayor (hoy es la calle de República de Bolivia, entre las de Brasil y Argentina).

${ }^{47}$ Además de las compañías que presentaban dramas y comedias, en los años que siguieron a la Independencia hubo distintos intentos por afianzar a las compañías de ópera con artistas provenientes de Europa. La más duradera, hasta ese momento, fue la que permaneció de 1831 a 1838, con temporadas poco exitosas y escasas ganancias para el empresario. 
misma capital del orbe Cristiano" se organizaban diversos festejos en los días de Carnaval. Y añadió:

Los gobiernos igualmente han advertido lo útil que es la reunión de los ciudadanos en un punto fijo en las épocas en que las costumbres del pueblo lo hacen entregarse á públicos regocijos. Reunidos aquellos en un local determinado, la policía vela y evita faltas y delitos que le sería imposible estorbar en una concurrencia privada. ${ }^{48}$

Esas razones, sumadas al deseo de que México gozara "de una diversión propia de todo país civilizado", fueron los argumentos que usó la compañía de teatro para pedir el permiso a la autoridad. El gobernador del departamento, Luis Gonzaga Vieyra, accedió a la petición y aprobó el reglamento propuesto. Éste incluyó, entre otras, las siguientes especificaciones:

Ningún máscara podrá introducirse en el salón con armas de ninguna especie. [...] Habrá una autoridad que presida la función. [...]

El baile comenzará a las nueve y concluirá á las cinco de la mañana. [...]

Cualquiera de los asistentes que porten careta y se descomidan, se les quitará á presencia de los concurrentes y se le[s] reprenderá por el Juez. [...]

No se permitirá ningún disfraz de eclesiástico de ambos sexos. ${ }^{49}$

Así, desde inicios de 1840, todo estaba dispuesto para la diversión: los bailes de máscaras se trasladarían a un espacio público; se convertirían en un espectáculo en el que los asistentes serían protagonistas y, al mismo tiempo, espectadores. Al gobierno le beneficiaría el carácter público de estas diversiones. Era, como la compañía dramática lo planteó, la oportunidad de llevar a un solo sitio diversiones que acostumbraban estar dispersas y lejos de la vigilancia gubernamental.

Al frente del gobierno de nuevo se encontraba Anastasio Bustamante, en su segundo periodo como encargado del poder ejecutivo (1837-1841); ahora en una república centralista regida por las "Siete Leyes" de 1836. A semejanza de inicios de 1831, Bustamante no contaba con un nutrido apoyo político. Los centralistas, quienes favorecieron su llegada al poder, estaban decepcionados e inconformes con la que consideraban una actitud indecisa de Bustamante, y más aún porque el presidente se acercó a los federalistas moderados al comienzo de su gobierno. Los federalistas en

${ }^{48}$ AGN, Justicia Archivo, v. 121, exp. 1 [1], f. 1.

${ }^{49}$ AGN, Justicia Archivo, v. 121, exp. 1 [1], f. 4. 
general se oponían a la constitución que regía al país, y los más radicales no simpatizaban con el presidente. Por su parte, los federalistas moderados también se decepcionaron cuando Bustamante no favoreció un intento de Manuel Gómez Pedraza por reformar la constitución a finales de $1838 .^{50}$

En cuanto a su relación con la Iglesia, Bustamante buscó que fuera cordial desde el principio de su administración; asimismo, según sus contemporáneos, valoraba el consejo de las autoridades eclesiásticas. ${ }^{51}$ La Iglesia, por su parte, había apoyado el establecimiento del centralismo. Después de las reformas y los proyectos del congreso radical de 1833, que amenazaron los bienes eclesiásticos y sus prerrogativas, el alto clero tomó una postura más activa contra el liberalismo que consideraba exaltado, por lo que consideró benéfico el cambio de régimen. No obstante, pronto tuvo sus reservas, en especial desde que el gobierno de Bustamante solicitó disponer de las propiedades eclesiásticas como garantía de los préstamos que solicitó a los agiotistas para sortear la deficiente recaudación y para enfrentar las guerras con Francia y Texas. ${ }^{52}$ Todo ello había desgastado la relación del presidente con la jerarquía eclesiástica. Llevar los bailes de máscaras de las casas al teatro le permitiría al gobierno estar en buenos términos con ella. Así se evitarían los abusos de años anteriores, en particular, el uso de disfraces religiosos que tanto preocupaba.

Cercana la fecha de los bailes, el prefecto de la ciudad, Tomás de Castro, escribió al ayuntamiento para que nombrara un juez que presidiera el espectáculo y que procurara que se cumpliera el reglamento. Castro mencionó que desde 1808, cuando surgieron los bailes en la capital, había habido desórdenes, en particular por los disfraces. "Pues habiendo sido los bailes en casas particulares, han estado fuera de la vista eficaz de la policía, habiendo disgustado al público sensato y piadoso con los trajes eclesiásticos con que se han presentado en las calles y Teatro." ${ }^{53}$ El prefecto puso en palabras el proceso de transición de las mascaradas desde la calle y las casas hacia un espacio público bien delimitado, observable y controlable. Y evidenció el beneplácito con que el Estado veía este traslado.

50 Andrews, Entre la espada y la Constitución..., 227-248.

51 Andrews, Entre la espada y la Constitución..., 291.

${ }^{52}$ Costeloe, La República Central en México..., 168-173; Brian Connaughton, Entre la voz de Dios y el llamado de la patria. Religión, identidad y ciudadanía en México (México: Fondo de Cultura Económica/Universidad Autónoma Metropolitana-Iztapalapa, 2010) 227-232; Andrews, Entre la espada y la Constitución..., 291.

${ }^{53}$ AGN, Justicia Archivo, v. 121, exp. 1 [1], f. 13. 
La preocupación que nueve años atrás mostró el cabildo de la catedral la compartía el gobierno. Puede pensarse que con ello la jerarquía católica estaba tranquila. Por lo menos ésta no expresó su descontento hacia los bailes públicos: las mascaradas en carnestolendas eran una costumbre tolerada desde años atrás. Con tal que el gobierno cuidara sus intereses, los clérigos permanecían en calma. O también puede ser que, ante la experiencia de nueve años atrás, los hombres de la Iglesia consideraron más prudente no manifestarse.

Resulta interesante notar que ya no sólo las autoridades católicas se interesaron en el control de los cuerpos. Con las medidas que tomó, como restringir el uso de ciertos disfraces y vigilar el comportamiento, también el gobierno se inmiscuía en el ámbito corporal. Siguiendo la propuesta de Norbert Elias, ${ }^{54}$ al promover la autocoacción de los asistentes a los bailes y el control de los impulsos, el Estado se erigía como civilizador. Había también en esto una disputa entre las autoridades civiles y la Iglesia.

No sólo los disfraces preocupaban al gobierno: también los posibles desórdenes. Por ello, el gobernador Vieyra encargó a Vicente Filisola, comandante general del departamento, que vigilara el teatro, sus alrededores y la ciudad en las noches de carnaval. Entre otras cosas, Vieyra le encargó impedir que se arrojaran "confites, garbanzos, o cualquier otra cosa" desde la cazuela hacia el patio, es decir, desde la parte más alta del teatro hacia la sección más cercana al escenario. ${ }^{55}$ El 1 de marzo, día del primer baile, el gobernador Vieyra advirtió al ayuntamiento que, en cuanto el orden se alterara, revocaría el permiso, pues la capital tenía "fijos los ojos en estos espectáculos" que se habían permitido "para disfrutar de una alegría racional y decente". ${ }^{56}$

Es evidente el temor de los gobernantes por la reunión de tantos individuos durante tantas horas. Las funciones de teatro no se extendían hasta las cinco de la mañana y en ellas los asistentes no tomaban bebidas alcohólicas ni danzaban de un lado para otro. Mucho menos, en medio de un ambiente festivo en el que los individuos adoptaban un papel radicalmente diferente al cotidiano. A pesar de ello, parecía mejor que los bailes fueran públicos a que se celebraran en espacios privados. El recelo de quienes estaban en el poder no era gratuito. La oposición al régimen existía desde

${ }^{54}$ Norbert Elias, El proceso de la civilización. Investigaciones sociogenéticas y psicogenéticas (México: Fondo de Cultura Económica, 2016).

55 AGN, Justicia Archivo, v. 121, exp. 1 [1], f. 18.

${ }^{56}$ AGN, Justicia Archivo, v. 121, exp. 1 [1], f. 20. 
que se instauró el centralismo y la amenaza de las rebeliones federalistas pendía sobre el gobierno constantemente. De hecho, los bailes se llevaron a cabo entre rumores de pronunciamientos y con la noticia de un levantamiento en Yucatán. ${ }^{57}$

No tan ilustrados

Desde que se conoció que habría bailes de máscaras en el Teatro Principal, se pronunciaron distintas voces al respecto. El Museo popular aplaudió la decisión. A inicios de año, escribió: "Nos alegramos de que en Méjico se introduzca esta costumbre, admitida de tiempo atrás en Europa; donde, según parece, se guarda mucho decoro en semejantes funciones. Creemos que nuestro público hará lo mismo, para dar una prueba de su circunspección y cultura". ${ }^{58}$

Los argumentos de los periódicos eran similares a los de la compañía dramática. Europa era el ejemplo a seguir y, si ahí se daba ese tipo de diversiones, en México también debía existir. Al parecer esta forma de razonar se difundió entre la élite urbana. Pero no todos tenían una visión tan monolítica ni idealizada de aquel continente. El Duende, un periódico de oposición, habló sobre los bailes desde inicios de febrero. ${ }^{59}$ En un artículo se burló del prefecto Tomás de Castro, quien supuestamente se oponía a las mascaradas, pero "tuvo que agachar la cabeza" ya que "el compadre [...] consiguió una orden de quien más podía". Dicho "compadre" era el coronel Manuel Barrera, empresario de la capital, muy cercano a Anastasio Bustamante. ${ }^{60}$ “¿Y todo por qué?”, preguntó El Duende. Y él mismo respondió:

57 “Yucatán”, El Cosmopolita, 29 de febrero de 1840, 4; Madame Calderón de la Barca, La vida en México durante una residencia de dos años en ese país (México: Porrúa, 1967), 85.

58 "Máscaras", El Museo popular, t. I, 1840, 66-67.

${ }^{59}$ El Duende fue una publicación semanal que circuló entre diciembre de 1839 y mayo de 1840. De tendencia liberal, con un tono satírico, criticó constantemente al gobierno. La mayoría de sus artículos están firmados con seudónimos, excepto colaboraciones de Pedro Fernández del Castillo y remitidos firmados por Manuel Altamirano y Juan de Dios Cañedo. Miguel Ángel Castro y Guadalupe Curiel, coords., Publicaciones periódicas mexicanas del siglo XIX: 1822-1855. Fondo Antiguo de la Hemeroteca Nacional y Fondo Reservado de la Biblioteca Nacional de México (Colección Lafragua) (México: Universidad Nacional Autónoma de México, Coordinación de Humanidades, Instituto de Investigaciones Bibliográficas, Seminario de Bibliografía Mexicana del Siglo xıx, 2000).

${ }^{60}$ Entre sus diversos negocios ligados a las diversiones, Barrera se desempeñó como empresario del Teatro Principal. 
...por beneficiar a los actores; porque el público se divierta, que está triste; [...] porque al ministerio homogéneo le gusta que haya baile, y siempre es bueno dar gusto a los que pueden dar empleos, favor y distinciones a nuestros hijos, sobre todo cuando ni los han ganado ni los merecen [...]; y porque en fin, es moda en Europa, y que nosotros no somos menos que nadie, y debemos marchar con el siglo y no quedarnos atrás en materias de tanta utilidad; y poco importa que no tengamos que comer, como haya que vender, ó que empeñar, ó a quien hacer estafa para ir al juego, a las máscaras y a los toros... ${ }^{61}$

En la visión de los editores de El Duende, ¿qué importaba parecerse a Europa o imitar sus costumbres si la ciudad y el país tenían problemas más urgentes que atender? No era un reclamo sin fundamento. Los habitantes de la ciudad, en particular los de los márgenes, corrían el riesgo de contagiarse de viruela por una epidemia que recorría la urbe. El Cosmopolita denunció que los cadáveres se llevaban descubiertos de San Pablo al panteón de Santa Paula. Esos "espectáculos de horror", afirmaron los editores, afectaban la moral de los habitantes y corrompían la atmósfera. El periódico pedía al ayuntamiento que difundiera un método para curar la enfermedad, ya que "los pobres" no contaban "con los recursos de quienes pueden tener médico a la cabecera”. ${ }^{62}$ Según las cifras que Carlos María de Bustamante registró, tomadas del Diario del Gobierno de la República Mexicana, entre el 1 de enero y el 7 de febrero de 1840 fallecieron 617 personas. ${ }^{63}$ La máscara de los pobres era la viruela.

Con el ambiente enrarecido, el 14 de febrero el Diario del Gobierno publicó el aviso de los bailes de máscaras en el Teatro Principal. Expresó que el gobernador concedió el permiso "en testimonio de su notoria ilustración, y de los nobles deseos que lo animan por contribuir de todos modos a la satisfacción y desahogo de los apreciables habitantes de esta capital". ${ }^{64}$ Pronto se colocaron los carteles de la compañía dramática con los precios de entrada (dos pesos en palcos y salón, un peso en la cazuela) y el reglamento aprobado para la ocasión. El cartel aseguraba que en todo "país culto" se solemnizaban los días de carnaval con bailes de máscaras públicos. En ellos la vigilancia de la policía “y más que todo la moralidad y

61 "Contesta Media sotana á su amigo Tente en el aire, que lo es muy suyo", El Duende, t. I, 8 de febrero de 1840, 91-93.

${ }^{62}$ El Cosmopolita, 12 de febrero de 1840, 4.

63 "Jueves 20 de febrero de 1840", Bustamante, Diario histórico de México...

64 “Máscaras”, Diario del Gobierno de la República Mexicana, 14 de febrero de 1840, 4. 
educación" de los concurrentes evitaban la transgresión del orden y de las "buenas costumbres". Según el anuncio, a la juventud de México se le había privado de una diversión pública que en "Venecia, Londres, París y hasta la misma capital del orbe cristiano" se disfrutaba desde tiempo atrás. El impreso de la compañía dramática terminaba subrayando que, tras los gastos y "sacrificios" realizados, correspondía "a los ilustrados mejicanos fomentar esa diversión propia de todo país civilizado". ${ }^{65}$

"Ilustrado", "civilizado", "culto" eran adjetivos que el cartel quería colgarle al país. La idea que difundía era que imitando las costumbres europeas se podían volver propias. Pero también el aviso del baile justificaba actos que implicaban un beneficio económico para los organizadores. Las mascaradas darían ganancias al empresario y al gobierno. ¿Y qué reproche se les podría hacer si mostrarían a la ciudad como la capital de una nación ilustrada, civilizada y culta? La oposición hizo varios: El Duende publicó un largo artículo para burlarse del aviso y del reglamento. Escribió que causaba "risa oír a estos pobres hombres hablar de la notoria ilustración" del gobernador Vieyra. Quien hubiera conocido antes al gobernador -afirmó El Duende - "creería que las luces les bajan del cielo á ciertas personas tan luego como empuñan un bastón de mando”. El periódico aprovechó para criticar las pocas medidas tomadas por el funcionario para mejorar el departamento en los diferentes ramos como caminos, alumbrado, escuelas, policía o establecimientos científicos. ${ }^{66}$

Según El Duende, Vieyra atropelló las leyes que prohibían las mascaradas. Aunque eran leyes de siglos anteriores, nadie las había derogado puesto que dichos recreos siempre habían conducido a desórdenes y excesos. Aseguró El Duende que "en todos los países cultos" las mascaradas habían estado prohibidas, aunque habían sido toleradas. El periódico rebatió el argumento de que dichas leyes ya no eran pertinentes por ser los hombres de la época "más prudentes e ilustrados". Citando a un filósofo, cuestionó la idea del progreso:

...nosotros sólo cambiamos de corteza y de vestido, el fondo permanece el mismo: [...] en nosotros no hay progreso real ni verdadera reforma: no hay más que una forma nueva aplicada a defectos y pasiones que tienen su origen en el principio del mundo; y sin embargo cada siglo se aplaude y se acaricia á sí mismo en su pequeña

${ }^{65}$ AGN, Justicia Archivo, v. 121, exp. 1 [1], f 10.

66 "Máscaras", El Duende, t. I, 22 de febrero de 1840, 109-110. 
y necia presunción: él pretende borrar todos los siglos que le han precedido, y si hubiéramos de creerlo, él solo es el que ha tenido talento y buen sentido, y el que ha descubierto el verdadero manantial de la felicidad pública... ${ }^{67}$

El Duende criticó el afán ilustrado de concebir a su época como la mejor que había vivido el hombre. Resulta interesante esta postura, pues contradice la idea del avance inevitable de la humanidad hacia el progreso, propia de la modernidad. ${ }^{68}$ Es también llamativo, porque El Duende era un periódico liberal y se decía vocero de la "verdadera Ilustración”. La crítica parece contradictoria; sin embargo, es la forma en que un sector de la élite intelectual se apropió del término.

A la compañía dramática también le respondió el diario. Ni su preocupación ni sus gastos y sacrificios debían estar enfocados a una diversión como las mascaradas. Su único objeto debía ser "corregir las costumbres", no "corromperlas con bailes de máscaras". Y sobre la presencia de éstos en Europa, afirmó El Duende que no provenía de la alta cultura ni de la Ilustración de los países; más bien, de su "licencia y desenfreno" o de "causas enteramente distintas de la civilización" (como las bacanales en la Antigüedad). Los gobiernos permitían los bailes de carnaval porque "los déspotas" no olvidaban la máxima: "Al pueblo es menester darle pan y circo para que no sienta el peso de sus cadenas ni despierte de su letargo”. Más adelante El Duende añadió: "No todo lo que hay en Londres y París es bueno, ni emana de su ilustración”, y recordó la violencia y la "inmoralidad" (peleas a puñetazos como espectáculo, prostitución, piezas "obscenas" en los teatros) de esas ciudades. ${ }^{69}$ El Duende invitó, con sarcasmo, a asistir al baile, advirtiendo con ello de todos los desórdenes y abusos que podrían desatarse:

Apresuraos padres de familia, id, llevad allí a vuestras hijas; corred maridos pundonorosos, llevad allí á vuestras esposas; fomentad esa diversión propia de todo país civilizado, y nada temáis, que las miradas atentas de la policía, la moralidad y educación, os ponen á cubierto de cuanto al oído pueda decírseles á vuestras hijas y consortes; de todo cuanto os puedan gritar y arrojar de las cazuelas, siendo quizá lo menos los alverjones. Allí todo ha de ser orden y si por algo se perturbare, inmediato al salón del baile se venden licores que lo restablecerán en el momento. ${ }^{70}$

\footnotetext{
67 "Máscaras", El Duende, t. I, 22 de febrero de 1840, 111-112.

${ }^{68}$ Hobsbawm, La era de la revolución..., 239.

69 “Máscaras”, El Duende, t. I, 22 de febrero de 1840, 112-114.

70 “Máscaras", El Duende, t. I, 22 de febrero de 1840, 114.
} 
Finalmente, El Duende se burló del reglamento aprobado. Señaló que las medidas atentaban contra la libertad de los ciudadanos. Y se preguntó: si las autoridades temían tantos desórdenes, ¿para qué hacían los bailes? Dijo además no entender el porqué de la prohibición de vestirse de religioso. En el teatro los cómicos se vestían de frailes y monjas "para ridiculizar el estado eclesiástico con los trajes, con las palabras y con las acciones", pero un cualquiera ¿̇no podía "ir disfrazado de monigote?". ${ }^{11} \mathrm{Al}$ final de su artículo, El Duende afirmó que los interesados por la moral y la verdadera Ilustración apreciarían el escrito como lecciones útiles. ${ }^{72}$

El Duende mostró una postura diferente a la del gobierno y a la que parte de la élite tenía. No todo a lo que se llamaba ilustrado lo era, o mejor dicho, cada uno lo entendía a su manera. Según el periódico había una "verdadera Ilustración" y ni el gobernador ni las mascaradas eran parte de ella. Esta idea justificaba la cita filosófica que negaba el progreso. Se había vuelto común calificar a los individuos y sus actos como ilustrados para aprobarlos y presentarlos como una versión superior a la del pasado. Quizá esto era lo pretencioso de la época.

Europa no era un modelo a seguir para todo y tampoco era homogénea. Como el texto de El Duende muestra, cuando los gobernantes y escritores mencionaban el continente, pensaban en Francia e Inglaterra y en menor medida en Italia, en específico Roma. Estas sociedades no eran monolíticas: en ellas había prácticas o costumbres ajenas a la Ilustración. No toda Europa ni los oriundos de dicho continente cabían en el molde ilustrado. La crítica iba contra la justificación de los gobernantes, pero también contra ciertos habitantes europeos de la ciudad de México. Dos años atrás, los reclamos de comerciantes franceses fueron el pretexto para una invasión gala a las costas veracruzanas. La misma Francia estaba en proceso de aceptar la independencia de Texas, que se había separado de México en 1836. Y debido a su herencia, que consideraban negativa, España también era mal vista por muchos liberales, como lo eran los editores de El Duende.

La otra preocupación de los escritores y periodistas de la época era la moralidad. Como señala Fernando Escalante, para los intelectuales y políticos, la inmoralidad era la causa de gran parte de los males del país y de su desencanto, y alejaba a la sociedad de la "civilización” y el orden cívico que imaginaban en otros sitios (Francia, España, Estados Unidos — variaba según

71 "Máscaras”, El Duende, t. I, 22 de febrero de 1840, 115-117.

72 "Máscaras”, El Duende, t. I, 22 de febrero de 1840, 117. 
la postura política-). ${ }^{73}$ Esto se aprecia en el artículo de El Duende, el cual asociaba la moralidad con el comportamiento racional o ilustrado. Por ello consideró inmorales los bailes de máscaras y los actos que el festejo podía provocar. De igual manera veía la embriaguez, las insinuaciones sexuales, los desórdenes o la violencia.

En otros casos, como el de Carlos María de Bustamante, la moralidad también comprendía los valores cristianos. El escritor se expresó sobre los bailes en un impreso que tituló La verdad sin máscara o las máscaras del carnaval desmascaradas. A diferencia de nueve años atrás, se opuso a ellos. En su argumento citó las leyes de Castilla, las cuales establecían que las mascaradas no iban "conforme al genio y recato de la nación española" y daban pie a las "ofensas a la majestad divina" y a innumerables males. Para Bustamante, el gobernador Vieyra había echado por tierra las leyes, las cuales debían estar por encima de los gobernantes.

Bustamante también se preocupó por los disfraces. Esto se debía, según afirmó, a lo que presenció en años anteriores cuando los bailes se prolongaron hasta la noche del Domingo de Pasión o Domingo de Ramos. A un costado de la catedral se podían ver reunidos "pontífices, obispos, cardenales, párrocos, y porción de frailes enlazados del brazo cada uno con una mujer vestida de monja, haciéndose mil almibaradas, contorciones y requiebros, cual pudieran unos enamorados sin término". Para Bustamante estos disfraces, que se burlaban de la religión y sus ministros, servían para familiarizar "al pueblo con el desprecio a estas personas venerables, y prepararlo a que llegue un día en que sean objetos de una desecha persecución y saña”. Como años atrás, admitió que los hombres necesitaban divertirse; pero ya no incluyó a los bailes en las opciones debido a su supuesta "inmoralidad”. También reprochó al gobierno que repartiera licencias, cuando en México abundaba la miseria y en las calles de la capital se veían pasar los cadáveres de las víctimas de la viruela. ${ }^{74}$

${ }^{73}$ Fernando Escalante Gonzalbo, Ciudadanos imaginarios (México: El Colegio de México, 1992), 13-19.

${ }^{74}$ Carlos María de Bustamante, La verdad sin máscara o las máscaras del carnaval desenmascaradas, citado en "Anexos. Febrero de 1840", Bustamante, Diario histórico de México... Al revisar su diario, el lector recibe la impresión de que, conforme avanzó el tiempo, el escritor vio con creciente nostalgia los años del gobierno español; o más bien, fue decepcionándose del rumbo que tomó el nuevo país. A principios de febrero de 1840, por ejemplo, Bustamante anotó en su diario el decoro con que el marqués de Vivanco, antiguo oficial del ejército del rey, portaba su uniforme. Y lo comparó con la poca dignidad con que lo llevaban los generales del ejército mexicano. 
Carlos María de Bustamante, como otros actores de la época, recurría a las leyes del gobierno español para asuntos que aún no habían sido normados por los mexicanos. Los regímenes postindependentistas no habían derogado ni sustituido las leyes hispanas, por lo que el escritor y muchos otros las consideraban vigentes. La legislación creada para la sociedad española siglos atrás pesaba más que las leyes incompletas de los gobiernos mexicanos. Por ello Bustamante citó dichas leyes y se opuso a los bailes. ${ }^{75}$

Aunque nueve años atrás minimizó la pena de la excomunión, en 1840 Bustamante se preocupó por las burlas a los clérigos y al culto. Bustamante era profundamente católico, y también con el transcurrir de los años se convirtió en un recio defensor de la religión. Le irritaba, por ejemplo, la irreligiosidad del presidente Anastasio Bustamante o del gobernador Vieyra, así como el desafío que muchos individuos lanzaban a la Iglesia. Había, en efecto, burlas a ella y los bailes de máscaras eran una oportunidad inmejorable para hacerlas.

Además de morales y religiosas, las críticas al gobernador y al presidente eran políticas. Las cargas fiscales irritaban a las élites, y la leva, a los sectores populares. Los militares estaban desgastados por el fracaso en Texas y por combatir con poco éxito las rebeliones federalistas, como la de Yucatán. ${ }^{76}$ La decisión del gobierno de permitir los bailes de máscaras públicos proveyó a sus opositores un nuevo pretexto para atacarlo.

A pesar de la tormenta, los primeros tres días de marzo de 1840 se efectuaron los primeros bailes de máscaras públicos en el Teatro Principal. Al término de esas jornadas el coronel José Mejía, alcalde primero del ayuntamiento, escribió un informe para el gobierno central. Reportó que, pese a los temores preexistentes de que los bailes tuvieran un carácter "tumultuoso y de licencia”, el orden reinó. Y que "sin embargo de la muy numerosa concurrencia de máscaras, y de personas no disfrazadas, mezcladas con aquellas [...], no se advirtió la más mínima falta contra la moralidad y decencia pública, y mucho menos contra el orden y [la] tranquilidad". ${ }^{77}$

Fanny Calderón de la Barca fue a uno de los bailes. Desde el palco en el que pasó la velada, entre pasteles y vino, vio a los asistentes bailar valses y galopes alrededor del lugar. Reseñó la variedad de disfraces: mujeres vestidas de hombres y viceversa, "poblanas de antifaz, sin medias y con

75 "Sábado 1 de febrero de 1840", Bustamante, Diario histórico de México...

${ }^{76}$ Costeloe, La República Central en México..., 196-207.

${ }^{77}$ Diario del Gobierno de la República Mexicana, 10 de marzo de 1840, 3. 
faldas demasiado cortas; caballeros armados; y buen número de trajes, probablemente prestados por la guardarropía del teatro, y un contingente aún mayor de lo usual, de tipos estrafalarios”. Entre las mujeres, según Calderón de la Barca, los disfraces que predominaron fueron los dominós, ${ }^{78}$ "adoptados por más encubridores, pues se estima en poco asistir a estos bailes”. ${ }^{79}$

A pesar de lo novedoso y del airado debate que provocaron, las mascaradas públicas de 1840 resultaron poco extraordinarias. Por lo menos así lo registraron quienes nos dejaron testimonio. Esto tranquilizó al gobierno centralista, pues las semanas previas a los bailes estuvieron cargadas de tensión. El hecho de que transcurrieran sin nada digno de anotar fue un alivio para las autoridades.

El ministro español Ángel Calderón de la Barca también dejó testimonio del baile al que asistió con su esposa la noche del 3 de marzo, martes de carnestolendas. Anotó en su diario:

El local era muy malo las más de las máscaras gente del pueblo modistas y artesanos franceses. Las S[eño]ras ó las que pretenden pasar por tales encerradas en los palcos desdeñando mezclarse con el pueblo y en silenciosa inanimada postura mirando estúpidamente a los danzantes. Habían corrido voces de que sucederían desórdenes. Nada ocurrió. ${ }^{80}$

Aunque breve, esta descripción de la velada nos ayuda a conocer mejor lo que significaron los bailes de máscaras en el Teatro Principal. Igual que su esposa, el ministro mencionó que no era bien visto asistir a estos bailes. Esa opinión seguramente la transmitieron a los Calderón algunas de las personas con las que socializaban. Es decir, individuos pertenecientes a la élite comerciante y propietaria de la capital, algunos de ellos españoles o con afinidad hacia España. Igualmente personas que, como Carlos María

${ }^{78}$ El dominó "era una capa amplia y larga con una capucha que cubría por completo a quien lo portaba, de ahí que se utilizara con cierta frecuencia [...], ya que al tener la mayoría de estas prendas un corte muy similar facilitaba que quien llevara un dominó pudiera pasar inadvertido o fuese confundido fácilmente". Ma. Esther Pérez Salas, "En busca de un disfraz para el carnaval. Oportunidad para lucir con ingenio", Bicentenario. El ayer y hoy de México 4, n. 13 (2010): 17.

${ }^{79}$ Calderón de la Barca, La vida en México..., 85.

${ }^{80}$ Ángel Calderón de la Barca, Diario de Ángel Calderón de la Barca, primer ministro de España en México. Incluye sus escalas en Cuba, ed., notas, estudio introductorio y epílogo de Miguel Soto (México: Secretaría de Relaciones Exteriores, Consultoría Jurídica, Dirección General del Acervo Diplomático/Southern Methodist University/William P. Clements Center for Southwest Studies, DeGolyer Library, 2012), 83. 
de Bustamante, se preocupaban por las expresiones anticlericales. Pero los bailes, aunque mal vistos por algunos, fueron concurridos, incluso por aquellos que los desdeñaban, como las señoras que se guardaron en sus palcos. Al final, muchos ocultaban su identidad tras una máscara y asistían a los bailes para participar en esa simulación pública y vigilada que era un carnaval, ya fuera por simple curiosidad.

Y si creemos lo que el ministro Calderón anotó, sabemos que no fue una diversión exclusiva de las élites. También participaron individuos de sectores medios, aquellos que podían sortear las barreras económicas que la diversión imponía (el disfraz, el coche, la entrada). Eran ellos a quienes Calderón se refería como "gente del pueblo". Así, aunque separados, distintos sectores de la sociedad se reunieron como sucedía en las funciones de teatro. Quizá éste fue otro motivo por el cual ciertos miembros de la élite abiertamente los despreciaron. Con sus mascaradas privadas en carnestolendas no se mezclaban con el resto de la sociedad ni revertían el orden social: simplemente se divertían e imitaban a su modo lo que se hacía en Europa. O bien, preferían permanecer lejos de la mirada de la autoridad.

Los motivos del gobernador para permitir los bailes públicos fueron de distinto orden: intentó restringir el número de mascaradas en domicilios particulares. Para eso facilitó la creación de un espacio público que le permitía vigilar e intervenir para evitar alteraciones al orden y ofensas a las autoridades civiles y eclesiásticas. Si bien el gobernador se ganó una andanada de críticas y burlas, cumplió con su objetivo.

El espacio público de los bailes de máscaras puede observarse siguiendo la propuesta de Geoff Eley. Para él, las barreras que dividen a la esfera pública de lo privado son permeables, como las que separan a dichas esferas del Estado, ya que éste busca influir en lo público ${ }^{81}$ En los espacios públicos de la ciudad de México (prensa, cafés, tertulias) había oposición al gobierno. Eran tan importantes que propiciaban cambios en el régimen. Los bailes de máscaras en casas, al igual que otras diversiones y espectáculos que se realizaban en la urbe eran parte de dichos espacios. Por ello, al trasladar las mascaradas a un lugar vigilado por las autoridades el gobernador buscaba influir en el espacio público y evitar desafíos a las autoridades eclesiásticas y, sobre todo, civiles, a las que él representaba.

${ }^{81}$ Geoff Eley, "Nations, Publics, and Political Cultures: Placing Habermas in the Nineteenth Century", en Culture/Power/History: A Reader in Contemporary Social Theory, ed. de Nicholas B. Dirks, Geoff Eley y Sherry B. Ortner (Princeton: Princeton University Press, 1994), 320. 
Otro interés fue el político. Al parecer las licencias concedidas permitieron a las autoridades mantener en paz a actores inestables, como los militares, quienes ese mismo año organizaron bailes particulares incluso durante la Cuaresma. ${ }^{82}$ El Cosmopolita así lo expresó. Mientras la epidemia de viruela seguía estragando, los gobernantes pensaban en otra cosa: "Los que han gastado miles de pesos en castillos y maromas piensan más en la calamidad de perder su puesto, que en la pública que arrebata á los pimpollos de la república". ${ }^{83}$ Finalmente, conceder licencias para las diversiones beneficiaba al ayuntamiento y al departamento. Los empresarios tenían que pagar una cuota para obtener el permiso. Ello explica que en los siguientes años, en los que el régimen estaba tan necesitado de recursos, concediera más licencias y admitiera bailes durante la Cuaresma.

Los bailes rumbo a medio siglo

En los años que siguieron a 1840 los bailes de máscaras públicos se consolidaron como una diversión y un espectáculo propios de la época de carnaval y de Cuaresma. El tiempo del año pensado por la Iglesia para la reflexión y la penitencia se convirtió poco a poco en una época para continuar los festejos en los que el orden social se modificaba y en los que se burlaba públicamente a instituciones como la eclesiástica. Todo ello era pasado por alto por quienes estaban en el poder, ante todo porque estas diversiones significaban un ingreso.

En 1841 el prefecto Estevan Villalva autorizó bailes en el Teatro Principal en los días previos al Miércoles de Ceniza y expuso los motivos de su decisión: dado que en años recientes las mascaradas se habían vuelto recurrentes, las leyes que las prohibían no podían seguir vigentes. "Prohibiciones ridículas" (como la excomunión) no iban a impedir que los ciudadanos organizaran sus diversiones. Por ello era mejor realizarlas en un punto determinado que pudiera ser vigilado por la autoridad. ${ }^{84}$ En 1842 el gobierno concedió una licencia para el primer domingo de Cuaresma. ${ }^{85} \mathrm{Y}$ en los años siguientes, los permisos se fueron ampliando. Para 1846 ya eran admitidos en los dos primeros domingos de Cuaresma. Las diversiones públicas

\footnotetext{
82 "Domingo 8 de marzo de 1840", Bustamante, Diario histórico de México...

${ }^{83}$ El Cosmopolita, 7 de marzo de 1840, 4.

${ }^{84}$ AGN, Justicia Archivo, v. 121, exp. 1 [3], fs. 7-8.

85 “Domingo 13 de febrero de 1842", Bustamante, Diario histórico de México...
} 
que antes se restringían en esa época ganaron terreno paulatinamente. $\mathrm{Si}$ bien los designios de la Iglesia anteriormente tampoco se cumplían a cabalidad, no se desobedecían con tal desenvoltura como en la década de 1840 . El dinero fue una pieza clave en este cambio.

Los bailes se volvieron un ingreso importante para las finanzas del ayuntamiento de la ciudad. Con el visto bueno del prefecto, los capitulares concedieron permisos a los empresarios de los teatros - quienes desempeñaron un papel destacado en el surgimiento y el auge de las mascaradas públicas-: al del Principal, donde comenzaron los bailes públicos, y al del Teatro Nacional o de Santa Anna, construido por Francisco Arbeu e inaugurado oficialmente en 1844 con bailes de máscaras. Por cada baile, el ayuntamiento cobraba entre 25 y 50 pesos a los empresarios. ${ }^{86} \mathrm{~A}$ pesar de las quejas de estos últimos, los capitulares difícilmente reducían la cuota, pues sabían que los bailes eran un buen negocio.

De los documentos de estos años rescato las adiciones al reglamento, las cuales permiten pensar en faltas que eran comunes y que los capitulares deseaban suprimir. Además de las prohibiciones de llevar armas y disfraces de religiosos, en enero de 1845 el prefecto Francisco Ortiz de Zárate añadió la de la venta de bebidas alcohólicas. Y dado que era imposible evitar que ciertas personas llegaran ebrias a los bailes, al notar su estado deberían retirarlas del lugar. También prohibieron los capitulares entrar con máscara a los palcos y a la galería alta; ${ }^{87}$ dicho de otra manera, a los lugares que no contaban con la vigilancia o la iluminación necesaria. En los primeros se encontraban los asistentes con más dinero; en la galería, los de las entradas menos costosas. Quizá consideraban que los desórdenes podían iniciar en esa parte de los teatros, y las máscaras permitían alterar a la concurrencia de forma anónima.

Entre 1841 y 1846 Carlos María de Bustamante siguió registrando en su diario las ocurrencias de los bailes de máscaras en carnestolendas y en Cuaresma. Continuó quejándose amargamente por su ocurrencia en esas semanas. Además, según anotó, cada año aumentó la asistencia de, en sus palabras, "gente ordinaria": "El pueblo bajo, es decir, [...] canalla, que afecta sobrepujar en excesos a la que se llama gente decente"... "léperos". En su caracterización, Bustamante englobaba también a sujetos como los militares

${ }^{86}$ Archivo Histórico de la Ciudad de México (en adelante Ансм), Ayuntamiento / Gobierno del Distrito, Diversiones públicas, v. 798, exp. 113, 135, 136, 138, 147, 163 y 169.

${ }^{87}$ Aнсм, Ayuntamiento / Gobierno del Distrito, Diversiones públicas, v. 798, exp. 147, fs. $2-3$. 
o los modistas franceses, hacia quienes constantemente mostraba desprecio, ya que para él, ellos representaban el deterioro de las costumbres, se alejaban de su idea de moralidad y dañaban al catolicismo. En 1846, escribió: "Últimamente la canalla soez de México quiere alternar con la gente decente. He aquí las causas porque tal vez se logrará en los años subsecuentes dar por el pie a esta manía tomada por imitación de los extranjeros, y arbitrio de chuparnos el dinero con el alquiler de sus vestidos". 88

Escritores más jóvenes que Bustamante, como Guillermo Prieto y Manuel Payno, apreciaban de forma un poco distinta los bailes. En la década de 1840 le dedicaron varias líneas a las mascaradas. Repitieron el argumento de El Duende de que los bailes no indicaban lo ilustrado de la sociedad mexicana y criticaron el afán de imitar todo lo europeo irreflexivamente. Pero al mismo tiempo mostraron cierto deleite por asistir. En sus relatos de costumbres, publicados bajo seudónimos en los diarios y revistas de la ciudad de México de los años cuarenta, evidenciaron este gusto y revelaron algunos detalles de los bailes. Por la tarde muchos enmascarados y comparsas desfilaban a pie o en coche por el paseo de $\mathrm{Bu}-$ careli y otros se divertían observándolos e intentando adivinar quién se escondía tras los disfraces. En la noche, camino al teatro, los que iban a los bailes y los transeúntes se divertían jugando bromas, reventando cascarones, gritando, chiflando, insultando e intentando desenmascarar a los demás. En el baile, en un teatro ricamente decorado, los disfraces permitían burlarse de las autoridades y de personajes públicos. Asimismo, el anonimato favorecía divertirse con menos inhibiciones: socializar, cortejar, bromear con mayor libertad. ${ }^{89}$

Aunque los escritores se burlaban de los asistentes que copiaban tristemente modas del exterior, que se sentían galanes, o de los dandys que se endeudaban para arreglarse y maquillarse, era innegable que también disfrutaban de los bailes porque conocían muy bien lo que sucedía en ellos. Décadas más tarde, Guillermo Prieto rememoró con nostalgia los bailes públicos de "Vieja", de "Piñata” y de "Fantasía", como se les llamó a los de los primeros tres domingos de Cuaresma. Describió la elegancia de los

88 "Jueves 3 de febrero de 1842", "Domingo 13 de febrero de 1842", "Miércoles de ceniza, 1 de marzo de 1843", "Miércoles 5 de febrero de 1845" y "Lunes 23 de febrero de 1846", Bustamante, Diario histórico de México...

${ }^{89}$ Carmen Alejandra Pascalin Camacho, "Bailes de máscaras. El carnaval de las élites en la ciudad de México: 1840-1860. El México que pinta la diversión y la empresa que la llevó a cabo" (tesis de maestría, Universidad Nacional Autónoma de México, 2009), 89-97. 
disfraces y a los personajes que asistían a ellos. ${ }^{90}$ Los escritores jóvenes de los cuarenta, aunque compartieron algunas opiniones con los de mayor edad como Carlos María de Bustamante, no mostraron la ojeriza que este último sí. Se percibe en esa década un cambio generacional, que salió a relucir en las opiniones sobre éste y otros espectáculos.

En sus recuerdos, Guillermo Prieto lamentó que "las invasiones de ebrios y gente ordinaria al teatro alejaron á la buena sociedad de él, y comenzó muy lentamente la marcada decadencia de las máscaras". ${ }^{91}$ La predicción de Carlos María de Bustamante resultó acertada. Los bailes públicos tuvieron su auge a mediados de siglo para después perder popularidad entre las élites.

Aunque de distinta forma y en distintos momentos, los dos escritores achacaron la decadencia de los bailes públicos de máscaras a la presencia cada vez mayor de individuos de sectores sociales no tan acomodados o con valores antagónicos a los de la élite intelectual. Es muy probable que muchas personas dejaran de asistir a los bailes públicos por la presencia de individuos de los sectores populares. La ausencia de ocupantes de palcos significó seguramente menores ganancias para los organizadores. Ello puede explicar el aparente decaimiento de esta diversión en la segunda mitad del siglo XIX.

\section{Reflexiones finales}

Los bailes de máscaras resultan un gran instrumento para acercarse a ciertos cambios que la sociedad mexicana experimentó en los años posteriores a la Independencia. El catolicismo rigió de manera estricta el ritmo de los días y los años en México hasta bien entrado el siglo xix. Las diversiones y los espectáculos públicos que se presentaban en cada época del año dependían del calendario litúrgico. Pero esto se secularizó. Aunque el calendario no se modificó, el Estado intervino en él. La Cuaresma dejó de ser un tiempo exclusivo para lo piadoso. Las disposiciones de los gobiernos civiles así lo fueron modificando. En este sentido, es visible el crecimiento de una cultura secular frente a una piadosa, y el desplazamiento de la Iglesia por parte del Estado.

Los bailes de máscaras, prohibidos a principios de siglo, fueron tolerados a partir de 1808. Para 1831 ya eran una costumbre en los días previos

${ }^{90}$ Guillermo Prieto, Memorias de mis tiempos (México: Porrúa, 2011), 163.

${ }^{91}$ Prieto, Memorias de mis tiempos, 163. 
a la Cuaresma. También se volvió común que en ellos los concurrentes se burlaran de las autoridades religiosas. Un intento de la Iglesia por dar marcha atrás a estas críticas aumentó su desprestigio y evidenció la separación de la sociedad y el clero. Hacia 1840, las autoridades y empresarios consideraban los bailes como un buen negocio económico y político. Para mediados de siglo, a pesar de burlar los símbolos religiosos, los bailes se aceptaban con naturalidad como un espectáculo público. Además, se toleraba que se celebraran en los domingos de Cuaresma. Para una ciudad en la que la Iglesia católica había sido parte central por tres siglos esto representaba un gran cambio. Si bien anteriormente también se pasaban por alto muchas normas de la Iglesia, este desafío se hacía con más restricciones por parte de las autoridades civiles y eclesiásticas y con menos descaro.

Como señala Brian Connaughton, la sociedad mexicana conservaba muchas costumbres religiosas pero también había adquirido o iba incorporando nuevas prácticas y nuevos valores que se mezclaban con dichas costumbres. Los individuos tenían diferentes maneras de experimentar o entender una misma religión. Y todo ello formaba parte del proceso de transformación que se vivía en la nueva nación. ${ }^{92}$ Un individuo podía ir a misa en la mañana, defender al gobierno mexicano por la tarde y asistir a un baile de máscaras en la noche sin abrigar contradicción alguna.

Finalmente, los casos que aquí estudio muestran que al gobierno le benefició que la diversión se efectuara en un espacio bien delimitado, en el que podía hacer sentir su presencia por medio de los funcionarios que vigilaban el orden. Asimismo, empresarios, artistas y autoridades vieron en los bailes de máscaras una oportunidad de obtener dividendos a partir de una diversión que causó entusiasmo entre las élites. La convirtieron en un espectáculo que trasladaron a escenarios teatrales en aras de obtener ganancias económicas.

Aunque las élites constriñeron el carnaval a lugares y momentos específicos, ocuparon parte del tiempo cuaresmal, es decir, traspasaron la barrera que antes dividía la vida carnavalesca y la vida penitente o contemplativa que, por lo menos en las intenciones de la Iglesia, seguía a los días de carnestolendas. Ambas etapas se difuminaron e irrumpieron una en la otra. De esta forma hubo templados días de carnaval seguidos de gozosos bailes de máscaras durante la Cuaresma.

${ }^{92}$ Connaughton, Entre la voz de Dios y el llamado de la patria..., 70-83. 


\section{FUENTES}

Archivos

Archivo General de la Nación (AGN), Ciudad de México, México.

Archivo Histórico de la Ciudad de México (Ансм), Ciudad de México, México.

\section{Hemerografía}

El Cosmopolita

Diario del Gobierno de la República Mexicana

El Duende

El Museo Popular

El Sol

Voz de la Patria

\section{Bibliografía}

Andrews, Catherine. Entre la espada y la Constitución. El general Anastasio Bustamante 1780-1853. Ciudad Victoria: Universidad Autónoma de Tamaulipas/H. Congreso del Estado de Tamaulipas, LX Legislatura, 2008.

Ávila, Alfredo. "La presidencia de Vicente Guerrero." En Gobernantes mexicanos. V. 1, 1821-1910, coordinación de Will Fowler, 75-96. México: Fondo de Cultura Económica, 2008.

Bajtin, Mijail. La cultura popular en la Edad Media y en el Renacimiento. El contexto de François Rabelais, traducción de Julio Forcat y César Conroy. Madrid: Alianza Universidad, 1998.

Bustamante, Carlos María de. Diario histórico de México 1822-1848, edición de Josefina Zoraida Vázquez Vera y Héctor Cuauhtémoc Hernández Silva. México: El Colegio de México/Centro de Investigación y Estudios Superiores en Antropología Social, 2001. CD-ROM.

Calderón de la Barca, Ángel. Diario de Ángel Calderón de la Barca, primer ministro de España en México. Incluye sus escalas en Cuba. Edición, notas, estudio introductorio y epílogo de Miguel Soto. México: Secretaría de Relaciones Exteriores, Consultoría Jurídica, Dirección General del Acervo Diplomático/Southern Methodist University/William P. Clements Center for Southwest Studies, DeGolyer Library, 2012.

Calderón de la Barca, Madame [Frances Erskine Inglis]. La vida en México durante una residencia de dos años en ese país. México: Porrúa, 1967. 
Castro, Miguel Ángel y Guadalupe Curiel, coords. Publicaciones periódicas mexicanas del siglo XIX: 1822-1855. Fondo Antiguo de la Hemeroteca Nacional y Fondo Reservado de la Biblioteca Nacional de México (Colección Lafragua). México: Universidad Nacional Autónoma de México, Coordinación de Humanidades, Instituto de Investigaciones Bibliográficas, Seminario de Bibliografía Mexicana del Siglo XIX, 2000.

Connaughton, Brian. Entre la voz de Dios y el llamado de la patria. Religión, identidad y ciudadanía en México. México: Fondo de Cultura Económica/Universidad Autónoma Metropolitana-Iztapalapa, 2010.

Corbin, Alain. "El dominio de la religión." En Historia del cuerpo. V. 2, De la Revolución Francesa a la Gran Guerra, coordinación de Alain Corbin, 57-86. Madrid: Taurus, 2005.

Costeloe, Michael P. La República Central en México, 1835-1846. "Hombres de bien" en la época de Santa Anna. México: Fondo de Cultura Económica, 2000.

Covarrubias, José Enrique. "Inútil e insociable. La Iglesia católica según la crítica sociológica de Fernández de Lizardi, Prieto y Ramírez, 1821-1876.” En El anticlericalismo en México, coordinación de Franco Savarino y Andrea Mutolo, 279-295. México: Cámara de Diputados/Instituto Tecnológico y de Estudios Superiores de Monterrey/Miguel Ángel Porrúa, 2008.

Dussel, Enrique. "La Iglesia en el proceso de la organización nacional y de los Estados en América Latina (1830-1880)." En Estado, Iglesia y sociedad en México. Siglo XIX, coordinación de Álvaro Matute, Evelia Trejo y Brian Connaughton, 63-80. México: Universidad Nacional Autónoma de México, Facultad de Filosofía y Letras/Miguel Ángel Porrúa, 1995.

Eisenstadt, Shmuel N. "Some Observations on Multiple Modernities." En Reflections on Multiple Modernities: European, Chinese and Other Interpretations, edición de Dominic Sachsenmaier y Jens Riedel con Shmuel N. Eisenstadt, 27-41. Leiden: Brill, 2002.

Eley, Geoff. "Nations, Publics, and Political Cultures: Placing Habermas in the Nineteenth Century." En Culture/Power/History: A Reader in Contemporary Social Theory, edición de Nicholas B. Dirks, Geoff Eley y Sherry B. Ortner, 297-335. Princeton: Princeton University Press, 1994.

Elias, Norbert. El proceso de la civilización. Investigaciones sociogenéticas y psicogenéticas. 4a. ed. México: Fondo de Cultura Económica, 2016.

Escalante Gonzalbo, Fernando. Ciudadanos imaginarios. México: El Colegio de México, 1992.

Fowler, Will. Santa Anna. ¿Héroe o Villano? México: Crítica, 2018.

García Ugarte, Marta Eugenia. “Anticlericalismo en México 1824-1891.” En El anticlericalismo en México, coordinación de Franco Savarino y Andrea Mutolo, 
319-350. México: Cámara de Diputados/Instituto Tecnológico y de Estudios Superiores de Monterrey/Miguel Ángel Porrúa, 2008.

Hale, Charles A. El liberalismo mexicano en la época de Mora (1821-1853). 15a. ed. México: Siglo XXI, 2005.

Hobsbawm, Eric. La era de la revolución 1789-1848. Barcelona: Crítica, 2011.

Martínez Domínguez, Laura. "El Sol, 1823-1835. Un periódico político durante la Primera República Federal.” Tesis doctoral. Universidad Nacional Autónoma de México, 2018.

Pascalin Camacho, Carmen Alejandra. "Bailes de máscaras. El carnaval de las élites en la ciudad de México: 1840-1860. El México que pinta la diversión y la empresa que la llevó a cabo." Tesis de maestría. Universidad Nacional Autónoma de México, 2009.

Pérez Salas, Ma. Esther. "En busca de un disfraz para el carnaval. Oportunidad para lucir con ingenio.” Bicentenario. El ayer y hoy de México 4, n. 13 (2010): 14-21. Prieto, Guillermo. Memorias de mis tiempos. 4a. ed. México: Porrúa, 2011.

Reyes de la Maza, Luis. El teatro en México durante la independencia (1810-1839). México: Universidad Nacional Autónoma de México, Instituto de Investigaciones Estéticas, 1969.

Tella, Torcuato S. di. Política nacional y popular en México, 1820-1847. México: Fondo de Cultura Económica, 1994.

Viqueira, Juan Pedro. ¿Relajados o reprimidos? Diversiones públicas y vida social en la ciudad de México durante el Siglo de las Luces. México: Fondo de Cultura Económica, 1987.

Zárate Toscano, Verónica. "Del regocijo a la penitencia o del carnaval a la Cuaresma en la ciudad de México en el siglo xix." En Gozos y sufrimientos en la historia de México, coordinación de Pilar Gonzalbo y Verónica Zárate, 203-234. México: El Colegio de México/Instituto de Investigaciones Dr. José María Luis Mora, 2007.

\section{SOBRE EL AUTOR}

Licenciado en Historia por la UNAM, maestro en Historia Moderna y Contemporánea, por el Instituto de Investigaciones Dr. José María Luis Mora, y doctor en Historia por el CIESAs Peninsular. Ha trabajado como docente en la Universidad Marista de Mérida y en la Universidad Abierta y a Distancia de México. Entre sus últimas publicaciones se encuentran "La ocupación estadunidense. Convivencia y diversión”, BiCentenario. El ayer y hoy de México 10, n. 40 (2018); y "Los problemas de una ocupación militar: el ejército estadounidense en el puerto de Veracruz, marzo de 1847-julio de 1848”, Ulúa. Revista de Historia, Sociedad y Cultura, n. 27 (2016). 